\title{
E-Transactions in Digital Era
}

\author{
R D Santy ${ }^{1^{*}}$, G H Hutomo ${ }^{2}$ \\ ${ }^{1}$ Departemen Manajemen, Universitas Komputer Indonesia, Indonesia \\ 2Departemen Sistem Informasi, Universitas Komputer Indonesia, Indonesia \\ Email: *raeny.dwisanty@email.unikom.ac.id
}

\begin{abstract}
The purpose of this research is to help marketplace providers utilize Ecommerce to improve their business. The method used in this study is a survey and literature study from research that has been done before. The results show that the role of the e-commerce market in online business transactions is useful to attract buyers. Starting from product marketing through media such as social media, websites, and advertisements. The role of E-commerce marketplace in online business transactions provides many benefits such as fast access to transactions, availability of goods, and ease of accessing the site.
\end{abstract}

\section{Introduction}

E-commerce market is a product of the advancement of technology, the needs of community will not be far from the development of information technology that exists now. Therefore, every company must be able to utilize information technology as one of the media to improve business. The use of information technology in the needs of the community has many benefits, one of which is as a means of obtaining information and can also be used in the field of online business. Especially now that there are so many companies that have used information technology to improve their business. According to the latest data released by We Are Social as of August 2018, the number of global internet users now touches the Figure of 3.8 billion with penetration of $51 \%$ of the total population in the world [1]. This increase was also claimed to rise $0.2 \%$ since April 2018. Citing information from official We Are Social information $41 \%$ of those accessing the internet came from websites. The rest comes from mobile devices, such as smartphones with a total of $54 \%$, tablets as much as $5 \%$, and other devices by $0.14 \%$ to customers [2].

There have been many previous studies conducted on the role of e-commerce marketplace in online business transactions. E-commerce marketplace is an infrastructure provider for companies to expand internal business processes to the external without having to face time and space obstacles [3], According to Selinger and Barrow, e-commerce marketplace is closely related to sales, advertising, product ordering, and all of which are done through the internet [4]. There are many companies using e-commerce marketplace in their business activities in addition to conventional business. 


\section{International Journal of Research and Applied Technology}

$1(2)(2021) 249-256$

Journal homepage: https://ojs.unikom.ac.id/index.php/injuratech

Therefore, the authors conducted research to determine the role of e-commerce marketplace in online business transactions. The research objective is to assist marketplace providers to be able to utilize E-commerce to improve their business and make it easier for marketplace providers to provide space in meeting community needs regarding product information offered.

\section{Method}

This research used qualitative method, this method describes the data obtained from the field survey that has been done, and also the existing theories. samples and information were also obtained about the use of e-commerce in online business transactions in companies in Indonesia. Therefore, this research is descriptive and inductive, where the existing data will be collected and given clear and detailed information. This study also looks at the phenomena that occur at this time so that research can focus on what is the current phenomenon. An example of a case study that used several samples as media support. Thus, the conducted research targeted to companies that has used E-commerce in the company so that later there will be a comparison with companies that have not used E-commerce.

\section{Results and Discussion}

\subsection{Literature Study}

There has been a lot of research done on the use of E-commerce in various fields, one of which is in the field of online business, therefore the authors conduct research on how the role of e-commerce marketplace in online business transactions so that marketplace providers can improve the quality of their products, as well innovative and interactive to make it more attractive to buyers. In order to avoid plagiarism, a literature review is needed to find out the results of previous studies.

According to Laudon, the role of E-commerce can be used in various fields, for example in the field of marketing [5]. The use of e-commerce as a media support will be helpful because e-commerce can market the product by adjusting to the needs of consumers thereby reducing the marketing of products that are less attractive to consumers. Meanwhile, according to the Mohapatra E-commerce marketplace has been widely used in various fields such as robots and businesses [6]. E-commerce marketplace can be used as a marketing tool or promotion that is more attractive, innovative and interactive.

From the results of previous research, it can be seen that the role of e-commerce marketplace in online business transactions can be more attractive, innovative and interactive which will make buyers interested in the products offered. With the development of existing technology, marketplace providers should be able to better utilize E-commerce in various aspects.

\subsection{Marketplace and E-commerce}

The marketplace is a business model, which makes a website not only help and promote its products but also facilitate online money transactions. In this online shopping system, a website also provides land or a place for sellers to sell their products. While the e-commerce shopping system is almost the same as the marketplace, that is, consumers just choose the desired product on a website, the difference is in e-commerce, 
International Journal of Research and Applied Technology

1(2)(2021) 249-256

Journal homepage: https://ojs.unikom.ac.id/index.php/injuratech

the product sold comes from the website it self. They do not open land or places for other sellers to sell their products.

\subsection{Case study}

In this section, the author will use examples of companies that have used E-commerce and marketplace in their businesses, for example, Bukalapak (See Figure 1).

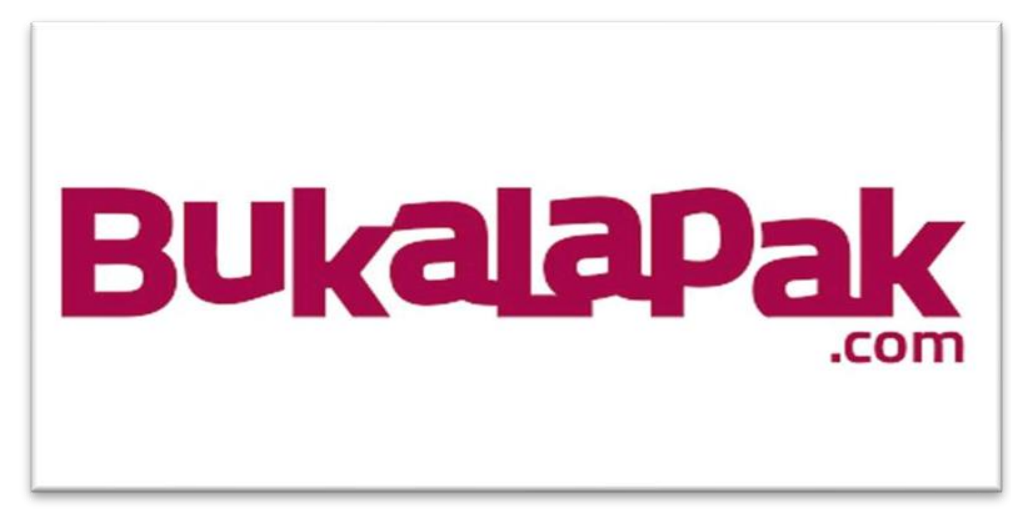

Figure 1. The company logo of Bukalapak

In Indonesia, the company that has become a provider of many marketplaces uses Ecommerce, therefore the authors take the example of Figure 1. Bukalapak applies the Customer to Business to Customer approach. Because it is known that the chances of success in this online business can be seen from the desire of the community who prioritize purchases that are practical, safe, easy, and reliable in meeting their needs. Here, Bukapalak understands the needs of the community, especially in Indonesia, because Bukalapak provides a place for sellers and buyers to make transactions, and what makes Bukalapak popular among the community is that they guarantees each transaction is safe from fraud because the buyer does not transfer money directly to the seller but through a bail account. Buyers' money can also be returned $100 \%$ if the product or goods purchased do not reach the buyer.

\subsection{SWOT analysis}

SWOT analysis is an identification in assessing the strengths and weaknesses of the resources owned by the company as well as assessing external opportunities and challenges faced [7]. Therefore, strategic planning must analyze the many factors that will be used later. Without careful planning, the company will not be able to run its business with maximum potential, and if you want to get maximum results, the company must make a mature strategic plan. According to Liu and Walsh, SWOT analysis is the method used to be able to observe the marketing environment in internal or external scope [8].

\subsection{The analysis in Product Performance}

When viewed from the conceptual side, a product is a subjective understanding, subjective itself from the seller's side, that is everything offered with the aim of being able to be purchased by the buyer or consumer to fulfill their needs. According to Ghoshal Products are goods or services that can be offered or sold in accordance with agreements and rules that apply in business [9]. 


\subsection{Work System at Bukalapak}

Bukalapak is a company engaged in the business of E-Commerce and marketplace $\neg$ which has a fairly good capital. The following will outline some of the work systems of Bukalapak, namely the registration of online customers or sellers. In this case, to be able to use the purchase and sale facilities, visitors must have an account after registering. Customer/seller profiles and customer/seller administration. Data that has been filled by visitors when registering will be stored in the database. Prospective buyers can see various products offered on the website. All forms of information related to products, prices, can be seen on the website. Offers and purchases can be made at the Bukalapak website. Bukalapak, in this case, applies for payment system payment, the buyer does not transfer money directly to the seller, but through a Bukalapak account. Buyers' money can also be returned $100 \%$ if the product or goods purchased do not reach the buyer.

\subsection{Feature Identification at Bukalapak}

The online business world of a product has an important meaning for the company. Bukalapak, in this case, offers products that are suitable for the needs of the community with the aim of developing broad marketing. Besides that, Bukalapak also provides a place for sellers who want to market their goods/ products[10].

In Figure 2, This feature serves to speed up the refund process, speed up the transfer of funds to the seller (remittance), and also provide an alternative method of payment that is easy and fast. The "Open Wallet" feature can be seen in the main menu list that contains transaction activity reports. Buyers/sellers can view transaction reports through "Open Wallet" and can also withdraw funds on the "Open Wallet" page. Disbursement of funds can be easily done by pressing select "liquidate" and provide information about the intended account and the password of the Bukalapak account afterward. 
International Journal of Research and Applied Technology

$1(2)(2021) 249-256$

Journal homepage: https://ojs.unikom.ac.id/index.php/injuratech

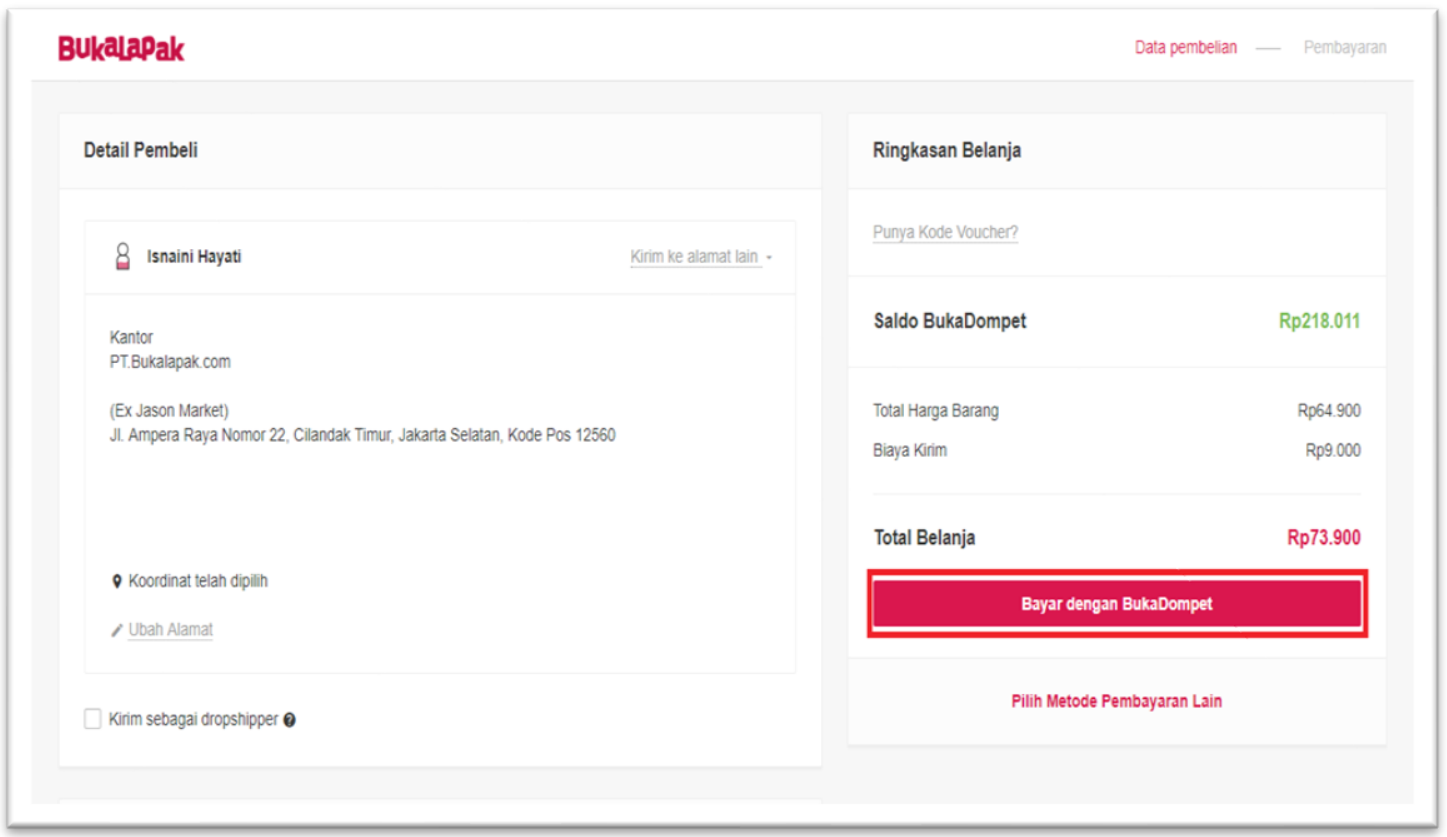

Figure 2. above is a feature to open the Bukalapak wallet

In Figure 3 and Figure 4, Push which means encouraging, Bukalapak will push certain products to appear at the front of the website page. This feature is made so that sellers can promote their items in the top or leading position of the item list page. Push transactions can only be done through "open wallet", and in "open wallet" there will be an option for a push. The seller must issue Rp. 500.00 for each push. At first glance, it might look cheap, but imagine how many items the seller has to push,Therefore, Bukalapak provides a list of packages that will ease the seller.

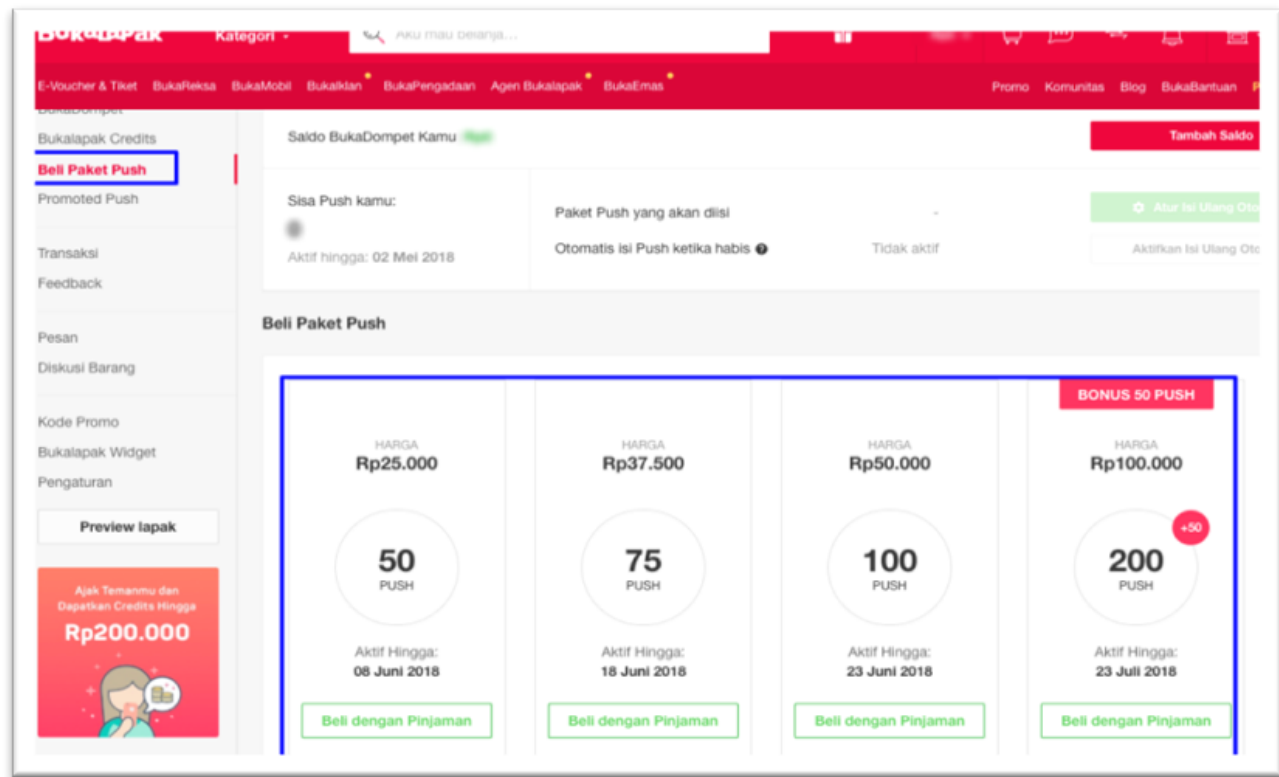

Figure 3. The Push purchase feature list of the Bukalapak push package 
International Journal of Research and Applied Technology

1(2)(2021) 249-256

Journal homepage: https://ojs.unikom.ac.id/index.php/injuratech

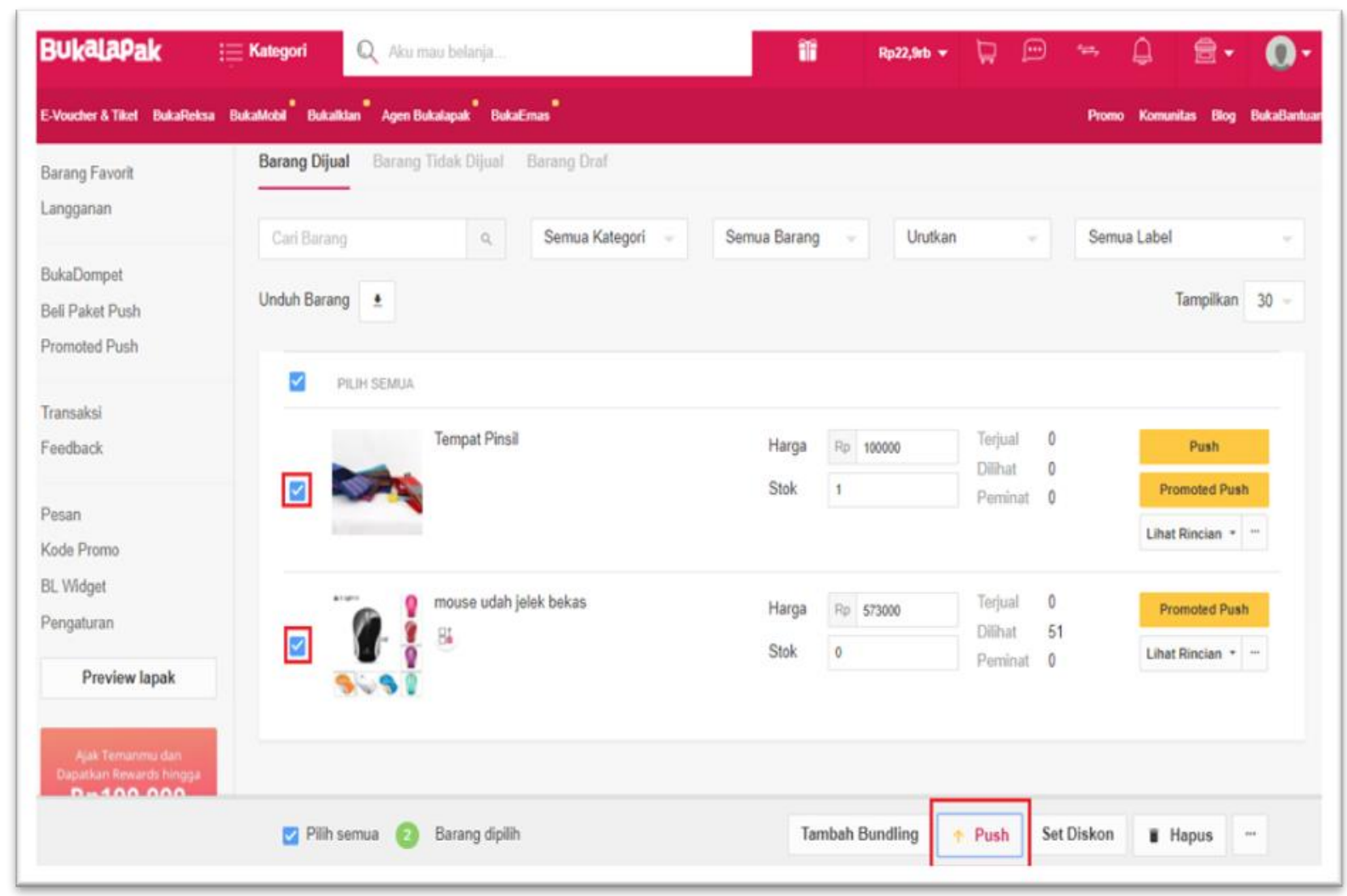

Figure 4. The Bukalapak push button

Uniquely, the push feature does not have a time limit, the remaining push can be accumulated with a new push purchase. Bukalapak also provides filters on the list of items that were last pushed.

In Figure 5 and Figure 6, The return feature functions as a return system, but of course with the condition that the mistake is made by the seller who sends the item not in accordance with the order. The return feature can only be done if the transactions that occur according to general tracking or the general tracking system on Bukalapak are still in active status. Own returns can be made if the buyer has not confirmed that the transaction has been completed. This return feature is provided by the Bukalapak product team to facilitate sellers and buyers who trade in Bukalapak. When the product or item has been received, the buyer immediately confirms and gives feedback on the system that is provided by Bukalapak. Then the buyer is allowed to submit a return if the item sent is not in accordance with the order. 
International Journal of Research and Applied Technology

$1(2)(2021) 249-256$

Journal homepage: https://ojs.unikom.ac.id/index.php/injuratech

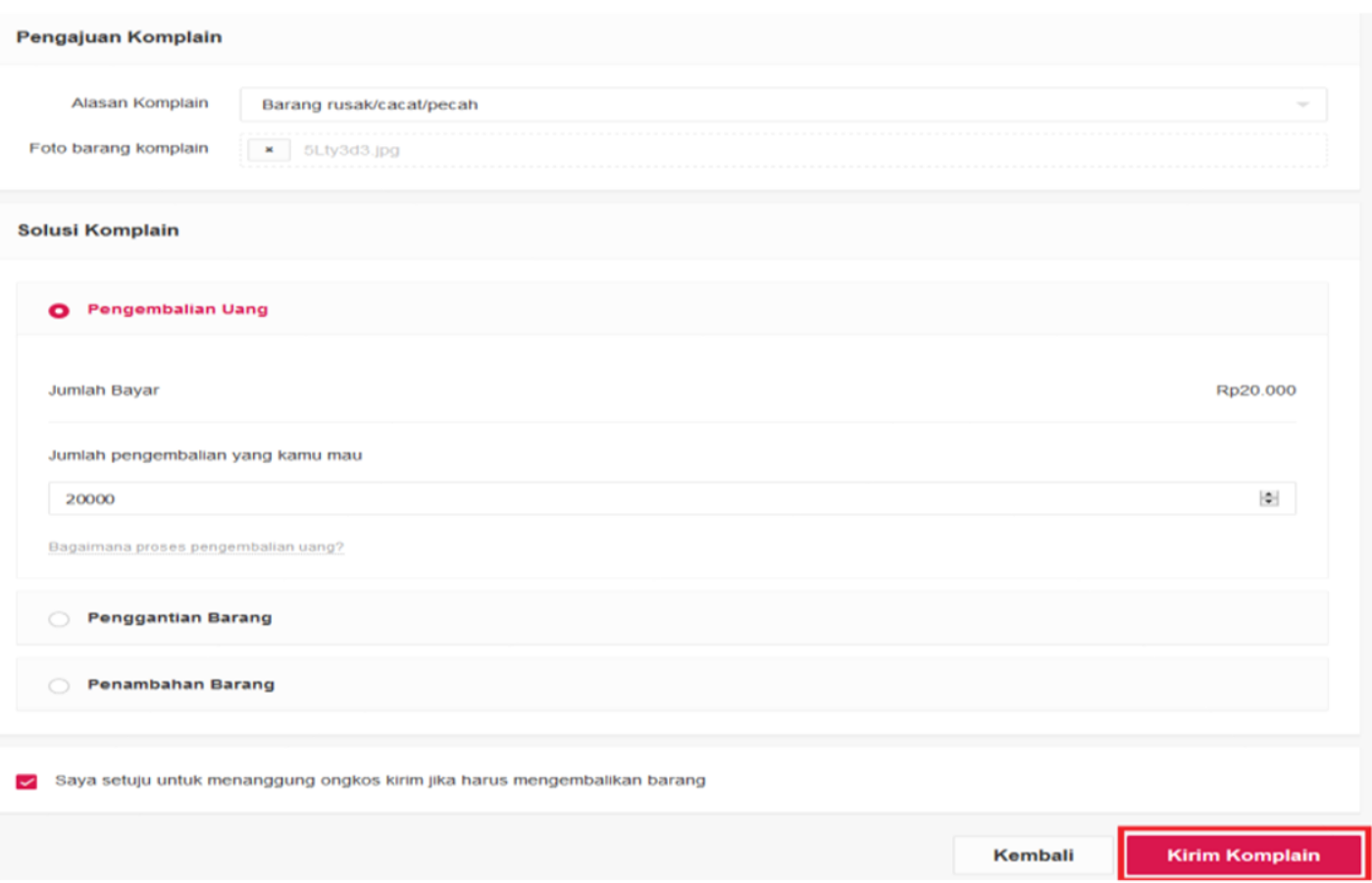

Figure 5. The Return feature to submit a complaint about the product of Bukalapak

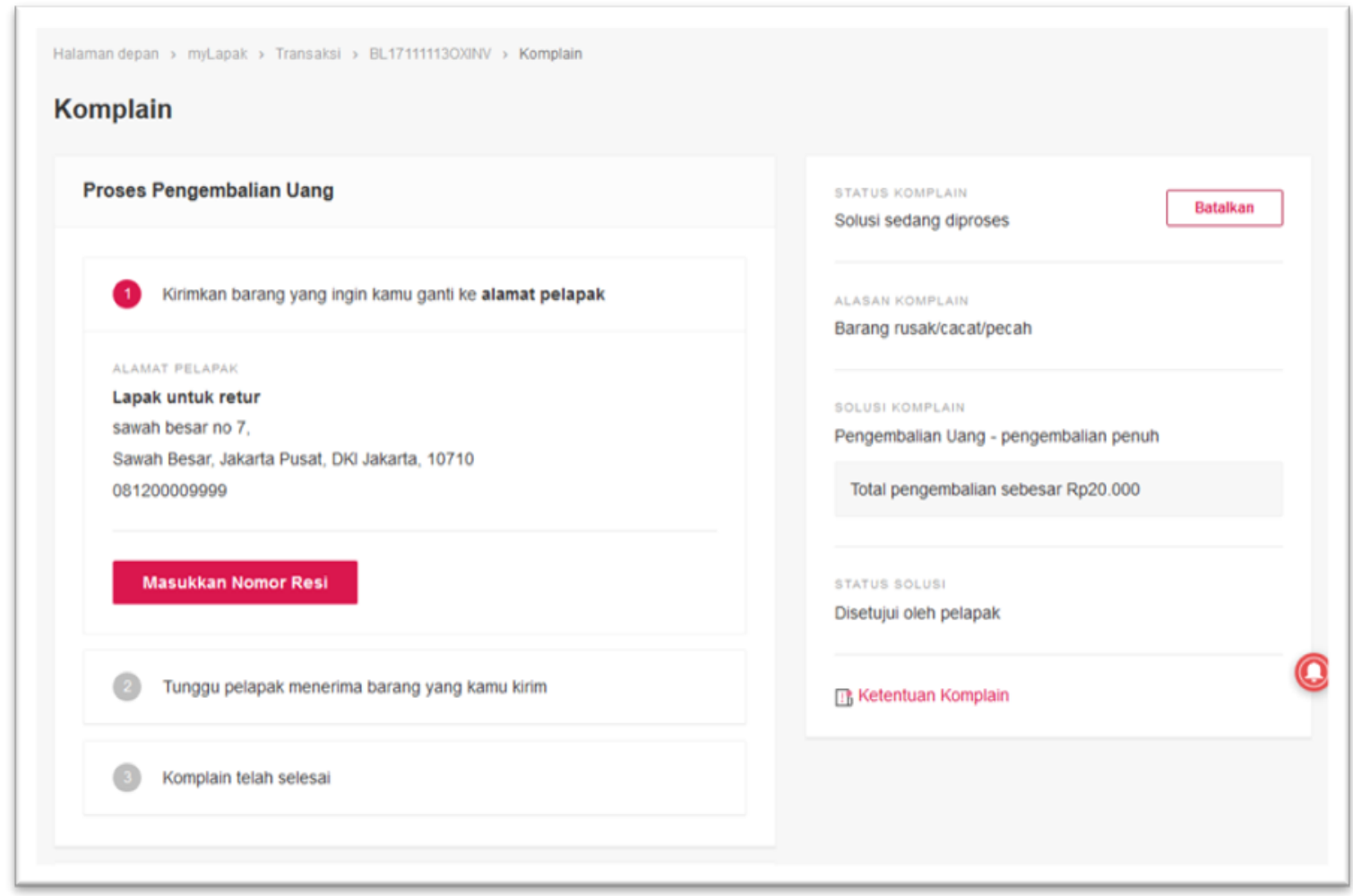

Figure 6. The Return feature after completing the submission of the goods complaint at Bukalapak 
International Journal of Research and Applied Technology

1(2)(2021) 249-256

Journal homepage: https://ojs.unikom.ac.id/index.php/injuratech

\section{Conclusion}

It can be concluded that with the role of e-commerce and marketplace in a company is attractive to customers, which causes Bukalapak to become one of the most popular ecommerce marketplace companies in Indonesia. At Bukalapak itself, the features needed by buyers or sellers are widely available. Bukalapak needs to improve and develop services such as purchasing bus tickets, boat tickets, and cinema tickets, and aggressively providing promos to users to compete with other similar E-Commerce.

\section{References}

[1] Zhao, W. X., Li, S., He, Y., Chang, E. Y., Wen, J. R., \& Li, X. 2016. Connecting social media to e-commerce: Cold-start product recommendation using microblogging information. IEEE Transactions on Knowledge and Data Engineering, 28(5), pp.1147-1159.

[2] Bakirtaş, H., \& Akkaş, C. 2017. Technology Readiness For New Technologies: An Empirical Study. Journal of International Social Research, 10(52), pp.1-9

[3] Garvey, J. C., Hart, J., Hoffman, G. D., Iverson, S. V., Metcalfe, A. S., Mitchell, T. D., ... \& Seher, C. L. 2017. Performing Critical Work: The Challenges of Emancipatory Scholarship in the Academic Marketplace. Critical Questions in Education, 8(2), pp.138-162.

[4] Huffman, B. J., \& Shenvi, R. A. 2019. Natural products in the "marketplace": interfacing synthesis and biology. Journal of the American Chemical Society, 141(8), pp.3332-3346.

[5] Kalia, P., Kaur, N., \& Singh, T. 2018. E-Commerce in India: evolution and revolution of online retail. In Mobile Commerce: Concepts, Methodologies, Tools, and Applications, pp. 736-758. IGI Global.

[6] Khaneghah, E. M., Shadnoush, N., \& Salem, A. 2017. Artemis time: A mathematical model to calculate maximum acceptable waiting time in B2C e-commerce. Cogent Business \& Management, 4(1), p.1405509.

[7] Januarti, E. K., \& Priantinah, D. 2018. Reviewing the Development of Information, Service, and Website Quality towards Traveloka Customer Satisfaction in Indonesia. Petra International Journal of Business Studies, 1(2), pp.63-69.

[8] Liu, X., \& Walsh, J. 2018. Study on the Strategies of the E-commerce Implementation in Binchuan Grape Industry of China- - Based on the SWOT Quantitative Analysis Method. Proceedings of Business and Economic Studies, 1(1), pp.7-13

[9] Soegoto, E. S., \& Rahman, R. A. (2021). Technology on E-Payment Systems. International Journal of Research and Applied Technology (INJURATECH), 1(1), 140-147.

[10] Soegoto, E. S. 2014. Entrepreneurship Menjadi Pebisnis Ulung Edisi Revisi. Elex Media Komputindo. 